\title{
Regional Variability in Hospital Mortality in Patients Hospitalized with ST-Segment Elevation Myocardial Infarction: Findings from the Gulf Registry of Acute Coronary Events
}

\author{
Lukman Thalib $^{\mathrm{a}}$ Mohammad Zubaid $^{\mathrm{a}}$ Wafa Rashed $^{\mathrm{b}}$ Wael Almahmeed $^{\mathrm{c}}$ \\ Jawad Al-Lawati ${ }^{d}$ Kadhim Sulaiman ${ }^{\text {e }}$ Ahmed Al-Motarreb $^{f}$ Haitham Amin ${ }^{g}$ \\ Jassim Al Suwaidi ${ }^{\text {h }}$ Khalid F. Alhabib ${ }^{i}$ \\ a Faculty of Medicine, Health Sciences Centre, Kuwait University, and b Mubarak Al Kabeer Hospital, Ministry of

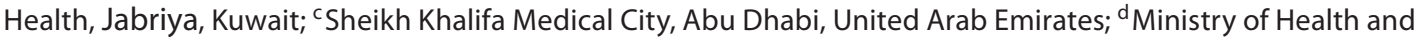

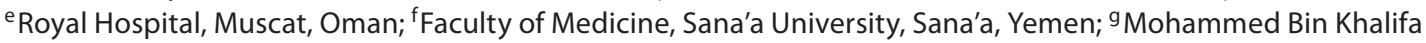 \\ Cardiac Center, Manama, Bahrain; h Hamad General Hospital, Doha, Qatar; 'College of Medicine, King Saud University, \\ Riyadh, Kingdom of Saudi Arabia
}

\section{Key Words}

In-hospital mortality $\cdot$ Acute coronary syndromes $\cdot$ Middle East $\cdot$ ST-segment elevation myocardial infarction

\section{Abstract \\ Objectives: To study the short-term mortality from ST-seg- ment elevation myocardial infarction (STEMI) in the Arabian Gulf region of the Middle East, and to examine whether these geographically and culturally related countries had similar or different outcomes. Subjects and Methods: The Gulf Registry of Acute Coronary Events recruited consecu- tive acute coronary syndrome patients from six Middle East- ern countries over a 5-month period. Results: Of 6,706 pa- tients recruited, 2,626 (39\%) had STEMI, and a total of 165 patients died in hospital, with a crude mortality rate of $6.3 \%$. However, mortality rates varied geographically between $10 \%$ in Yemen, 9.6\% in Oman and 3.3\% in the other countries. The unadjusted odds ratio of mortality for Yemen was 3.2 (95\% Cl: 2.2-4.7), and 3.1 (95\% Cl: 1.9-4.8) for Oman, com- pared to other Gulf countries. Even after adjusting for age}

and gender, the mortality remained significantly higher, almost double, in Oman and Yemen compared to other countries. This could be understood in the light of significant differences in a number of practice pattern variables such as reperfusion therapy, timely presentation and use of evidence-based medications. Conclusion: We found significant variability in STEMI mortality among Gulf Arab countries and identified areas requiring further efforts to reduce excess mortality in the region.

Copyright $\odot 2011$ S. Karger AG, Basel

\section{Introduction}

A regional analysis of the process of care and outcomes for a well-defined disease condition is important as it enables researchers to identify targets for regional quality improvement efforts and to design interventions to reduce inappropriate variations in care. Prior studies of patients with acute myocardial infarction have demonstrated marked geographical variation in patient treatment

\section{KARGER}

Fax +4161306 1234

E-Mail karger@karger.ch

www.karger.com
(C) 2011 S. Karger AG, Basel

1011-7571/11/0203-0225\$38.00/0

Accessible online at:

www.karger.com/mpp
Lukman Thalib

Department of Community Medicine and Behavioural Sciences Faculty of Medicine, Health Sciences Centre, Kuwait University PO Box 24923, Safat 13110 (Kuwait)

Tel. +965 2498 6779, Fax +965 2533 4968, E-Mail lthalib@ hsc.edu.kw 
Table 1. Variability in crude and age-adjusted STEMI mortality between different Gulf countries

\begin{tabular}{|c|c|c|c|}
\hline & Yemen & Oman & $\begin{array}{l}\text { Other Gulf } \\
\text { countries }^{1}\end{array}$ \\
\hline Number of patients & 779 & 406 & 1,441 \\
\hline Number of deaths & 78 & 39 & 48 \\
\hline Mortality rate & $10.0 \%$ & $9.6 \%$ & $3.3 \%$ \\
\hline \multirow{3}{*}{$\begin{array}{l}\text { Crude OR } \\
\text { Age-adjusted OR } \\
\text { Age- and gender- } \\
\text { adjusted OR }\end{array}$} & $3.2(2.2-4.7)$ & $3.1(1.9-4.8)$ & reference \\
\hline & $2.2(1.5-3.2)$ & $2.2(1.4-3.5)$ & reference \\
\hline & $2.2(1.5-3.2)$ & $2.2(1.4-3.4)$ & reference \\
\hline
\end{tabular}

Values in parentheses denote $95 \%$ CI.

${ }^{1}$ These include Bahrain, Kuwait, Qatar and the UAE. and outcomes [1-6]. Variations in the rates of case fatality, primary percutaneous coronary intervention (PCI), diagnostic angiography and the use of evidence-based therapies have been reported both regionally and within countries. Recognition of this disparity led to a number of quality improvement projects related to the process of care $[5,6]$.

The World Health Organization has predicted that cardiovascular disease (CVD) will be the leading cause of mortality and morbidity in developing countries by the year 2020 [6]. The Gulf region of the Middle East is part of the developing world that has seen significant socioeconomic transition over the past 40 years, leading to increase in risk factors like obesity, diabetes, hypertension and smoking [7]. As such, CVD burden in this region is expected to increase. One important aspect of combating disease in any given region is formulating unified policies and treatments that will not only reduce the impact of a disease, but will also result in the improvement or the predictability of mortality across the region. To that end we wanted to determine the mortality from ST-segment elevation myocardial infarction (STEMI) in the Gulf region of the Middle East, and to examine whether these geographically and culturally related countries had similar outcomes from treating the same disease.

\section{Subjects and Methods}

The Gulf Registry of Acute Coronary Events (Gulf RACE) is a Gulf Heart Association project. It is a prospective, multinational, multicenter survey of patients hospitalized with the final diagno- sis of acute coronary syndrome (ACS) in six Middle Eastern Gulf countries. The participating countries were Bahrain, Kuwait, Qatar, Oman, the United Arab Emirates (UAE) and Yemen. The study received ethical approval from the institutional ethical bodies in all participating countries. The study recruited consecutive ACS patients from 64 hospitals in these countries. In Bahrain, Kuwait and Qatar, all hospitals nationwide that admit patients with ACS participated in the survey. In Oman, the UAE and Yemen, most hospitals (covering at least $85 \%$ of the population) participated in the survey. It was carried out from January 29, 2007, and continued for 5 months. The registry protocol mandated enrolment of all consecutive ACS patients and left their management and daily care to the discretion of the treating physician. Full details of the methods have been described elsewhere [7]. Briefly, diagnosis of the different types of ACS and definitions of data variables were based on the American College of Cardiology clinical data standards [8]. For this report, all those admitted to the hospitals with definite changes on the electrocardiogram indicative of acute STEMI, or new or presumed new left bundle branch block myocardial infarction were grouped as STEMI. We report here on the final 5-month phase of the registry.

\section{Statistical Methods}

The differences in patient characteristics, risk factors, in-hospital treatments and hospital outcomes between countries were assessed using the $\chi^{2}$ test in case of categorical data, and the Kruskal-Wallis test in case of continuous variables. It should be noted that since countries other than Yemen and Oman had statistically similar mortality rates, we combined these countries to form three groups - Yemen, Oman and other Gulf countries - in our analysis. Logistic regression models were used to compare the inhospital mortality among countries. Further multivariate logistic regression models were used to adjust for age as well as other confounders. We reported crude and adjusted odds ratios (OR) along with $95 \%$ confidence intervals (95\% CI). Potential confounders such sociodemographic characteristics, clinical presentation at admission, risk factors, in-hospital treatments and process of care variables were compared between these countries to explain differences in mortality.

\section{Results}

A total of 2,626 STEMI patients were enrolled from 64 hospitals during the 5-month period between January and June 2007, and 165 patients died in hospital, leading to a crude mortality rate of $6.3 \%$. Yemen $(10 \%)$ and Oman (9.6\%) had significantly higher crude mortality rates than other countries (3.3\%). After adjusting for age, STEMI mortality between countries remained significantly different (table 1). Crude OR associated with STEMI mortality were 3.2 for Yemen and 3.1 for Oman, and the corresponding age-adjusted OR were 2.2 for both Yemen and Oman when the other four Gulf countries were taken together as the reference. These differences remained even when adjusted for both age and gender using multivariate models. 
Table 2. Variability in the clinical characteristics, risk profile and time to presentation of STEMI patients admitted to hospitals in different Gulf countries

\begin{tabular}{|c|c|c|c|c|c|}
\hline & All & Yemen & Oman & Other Gulf countries ${ }^{1}$ & $\mathrm{p}$ \\
\hline Total number & 2,626 & 779 & 406 & 1,441 & \\
\hline Age, years & $53(16)$ & $60(18)$ & $55(18)$ & $50(13)$ & $<0.001$ \\
\hline Male gender & $2,260(86.1 \%)$ & $632(81.1 \%)$ & $329(81.2 \%)$ & $1,299(90.2 \%)$ & $<0.001$ \\
\hline Citizens $^{2}$ & $1,292(49.2 \%)$ & $776(99.6 \%)$ & $261(64.3 \%)$ & $297(20.6 \%)$ & $<0.001$ \\
\hline Any past CVD history ${ }^{3}$ & $680(25.9 \%)$ & $225(28.9 \%)$ & $114(28.1 \%)$ & $341(23.7 \%)$ & 0.015 \\
\hline \multicolumn{6}{|l|}{ Key risk factors } \\
\hline Diabetes mellitus & $848(32.3 \%)$ & $200(25.7 \%)$ & $124(30.6 \%)$ & $524(30.6 \%)$ & $<0.001$ \\
\hline Hypertension & $454(17.3 \%)$ & $72(9.2 \%)$ & $90(22.2 \%)$ & $292(20.3 \%)$ & $<0.001$ \\
\hline Hyperlipidemia & $355(13.5 \%)$ & $102(13.1 \%)$ & $44(10.8 \%)$ & $209(14.9 \%)$ & 0.145 \\
\hline Current smoker & $1,322(50.3 \%)$ & $389(49.9 \%)$ & $145(35.7 \%)$ & $788(54.7 \%)$ & $<0.001$ \\
\hline Body mass index & $25.9(5.6)$ & $25.7(5.5)$ & $25.5(5.3)$ & $26.2(5.7)$ & $<0.001$ \\
\hline Any comorbidities ${ }^{4}$ & $220(8.4 \%)$ & $107(13.7 \%)$ & $34(8.4 \%)$ & $79(5.5 \%)$ & $<0.001$ \\
\hline Killip class $>\mathrm{I}$ & $535(20.4 \%)$ & $211(27.1 \%)$ & $94(23.2 \%)$ & $230(16.0 \%)$ & $<0.001$ \\
\hline \multicolumn{6}{|l|}{ Presenting symptoms } \\
\hline Ischemic chest pain & $2,314(88.2 \%)$ & $653(83.8 \%)$ & $347(85.5 \%)$ & $1,314(91.4 \%)$ & $<0.001$ \\
\hline Atypical chest pain & $109(4.2 \%)$ & $47(6.0 \%)$ & $15(3.7 \%)$ & $47(3.3 \%)$ & $<0.001$ \\
\hline Dyspnea & $114(4.3 \%)$ & $55(7.1 \%)$ & $18(4.4 \%)$ & $41(2.9 \%)$ & $<0.001$ \\
\hline \multicolumn{6}{|l|}{ Vital signs at admission } \\
\hline Heart rate, bpm & $83.0(28.0)$ & $90.0(20.0)$ & $80.0(26.0)$ & $80.0(24.0)$ & $<0.001$ \\
\hline Systolic blood pressure, $\mathrm{mm} \mathrm{Hg}$ & $130.0(35.0)$ & $130.0(40.0)$ & $130.0(40.0)$ & $138.0(36.0)$ & $<0.001$ \\
\hline First blood glucose, $\mathrm{mM}$ & $8.6(6.6)$ & $8.1(4.6)$ & $8.2(6.3)$ & $9.0(7.1)$ & $<0.001$ \\
\hline Fasting blood glucose, $\mathrm{mm}$ & $14.4(2.7)$ & $13.1(2.8)$ & $14.0(3.0)$ & $14.9(2.1)$ & $<0.001$ \\
\hline
\end{tabular}

Values for age, body mass index and vital signs at admission are medians with interquartile ranges in parentheses.

${ }^{1}$ These include Bahrain, Kuwait, Qatar and the UAE. ${ }^{2}$ Citizens here indicate the locals who are citizens of the countries as Gulf countries have large expatriate populations who are noncitizens. ${ }^{3}$ Any previous history of myocardial infarction, angina, PCI or coronary artery bypass surgery. ${ }^{4}$ Comorbidities included stroke, peripheral vascular disease, chronic obstructive pulmonary disease or dialysis.

In an attempt to explain the observed differences in STEMI mortality between the countries, we evaluated the differences in age and gender, ACS risk factors, presenting symptoms and comorbidities (table 1). Patients' median ages in Yemen and Oman were 5 and 10 years higher, respectively, compared to other countries. Yemen and Oman also had a significantly higher proportion of females. Although the proportion of patients with past CVD history or any other comorbid conditions was slightly higher in Yemen and Oman, the prevalence of CVD risk factors at admission was relatively lower in these two countries. In terms of clinical presentation, almost 27\% in Yemen and 23\% in Oman presented with Killip class of more than I, compared to only $16 \%$ in other Gulf countries. Other clinical characteristics at admission, such as heart rate, blood pressure and glucose levels, were also different among countries.
Important aspects of hospital care like the use of thrombolytic therapy and evidence-based medications are given in table 2. Fewer patients were eligible for reperfusion therapy in Yemen and Oman due to late hospital presentation compared to other countries. In Yemen, 37\% of the patients arrived at hospital within $12 \mathrm{~h}$ of symptom onset, compared to $78 \%$ in Oman and $84 \%$ in other Gulf countries. The reperfusion shortfall, defined as the proportion of eligible patients who did not receive reperfusion, was $18.6 \%$ in Yemen, $7.8 \%$ in Oman and $6.7 \%$ in other Gulf countries. Furthermore, for those who received thrombolytic therapy, the median door-to-needle time was $51 \mathrm{~min}$ in Oman, compared to 45 and $42 \mathrm{~min}$ in Yemen and other countries, respectively. Oman had the lowest utilization of clopidogrel and heparin, while the use of glycoprotein IIb/IIIa inhibitor was negligible in Yemen and Oman, with only $1-2 \%$ of patients receiving it compared to $13 \%$ in other countries (table 3). 
Table 3. Variability in presentation times, hospital treatments and outcomes of STEMI patients stratified by country

\begin{tabular}{|c|c|c|c|c|c|}
\hline & All & Yemen & Oman & Other Gulf countries ${ }^{1}$ & $\mathrm{p}$ \\
\hline Total number & 2,626 & 779 & 406 & 1,441 & \\
\hline Symptom onset to presentation $\leq 12 \mathrm{~h}$ & $1,799(69.1 \%)$ & $285(36.7 \%)$ & $309(77.8 \%)$ & $1,205(84.4 \%)$ & $<0.001$ \\
\hline Primary $\mathrm{PCI}^{2}$ & $146(8.1 \%)$ & $10(3.5 \%)$ & $5(1.6 \%)$ & $131(10.9 \%)$ & $<0.001$ \\
\hline Reperfusion shortfall ${ }^{2}$ & $158(8.8 \%)$ & $53(18.6 \%)$ & $24(7.8 \%)$ & $81(6.7 \%)$ & $<0.001$ \\
\hline Door-to-needle time ${ }^{2}, \min$ & $45(41)$ & $45(30)$ & $51(69)$ & $42(44)$ & 0.003 \\
\hline Aspirin & $2,580(98.3 \%)$ & $753(96.8 \%)$ & $400(98.8 \%)$ & $1,427(99.0 \%)$ & $<0.001$ \\
\hline$\beta$-Blockers & $1,639(62.4 \%)$ & $452(58.1 \%)$ & $231(57.0 \%)$ & $954(66.3 \%)$ & $<0.001$ \\
\hline Statin & $2,482(91.9 \%)$ & $676(86.8 \%)$ & $352(86.7 \%)$ & $1,384(96.0 \%)$ & $<0.001$ \\
\hline ACEI/ARB & $1,817(69.3 \%)$ & $577(74.1 \%)$ & $266(65.8 \%)$ & $974(67.6 \%)$ & 0.002 \\
\hline Clopidogrel & $1,565(59.6 \%)$ & $457(58.7 \%)$ & $126(31.0 \%)$ & $982(68.1 \%)$ & $<0.001$ \\
\hline Heparin & $2,409(91.7 \%)$ & $766(98.3 \%)$ & $242(59.6 \%)$ & $1,401(97.2 \%)$ & $<0.001$ \\
\hline Cardiogenic shock & $238(9.1 \%)$ & $100(12.8 \%)$ & $52(12.8 \%)$ & $86(6.0 \%)$ & $<0.001$ \\
\hline Reinfarction & $59(2.2 \%)$ & $7(0.9 \%)$ & $12(3.0 \%)$ & $40(2.8 \%)$ & 0.010 \\
\hline Stroke & $31(1.2 \%)$ & $13(1.7 \%)$ & $9(2.2 \%)$ & $9(0.6 \%)$ & 0.010 \\
\hline Major bleeding & $31(1.2 \%)$ & $4(0.5 \%)$ & $9(2.2 \%)$ & $18(1.2 \%)$ & 0.033 \\
\hline Hospital stay, days & $5(3)$ & $7(4)$ & $5(3)$ & $5(3)$ & $<0.001$ \\
\hline
\end{tabular}

Values for door-to-needle time and hospital stay are medians with interquartile ranges in parentheses. ACEI = Angiotensin-converting enzyme inhibitor; $\mathrm{ARB}$ = angiotensin receptor blocker; GPI = glycoprotein IIb/IIIa inhibitor.

${ }^{1}$ These include Bahrain, Kuwait, Qatar and the UAE. ${ }^{2}$ Only patients eligible to receive reperfusion therapy were analyzed.

\section{Discussion}

We found significant disparity in STEMI mortality across the countries on the Arabian Gulf peninsula. Yemen and Oman had higher STEMI mortality than the other countries in the region. To our knowledge, this is the first study that reports CVD outcomes across Middle Eastern countries. Disparities in cardiovascular and other health outcomes across geographical regions have previously been reported from other parts of the world [1-5]. The higher STEMI mortality in Yemen and Oman, almost 3-fold higher in crude rates, compared to the other Gulf countries might be partly linked to the fact that they had patients who were almost 5-10 years older. It is known that hospital and 1-year mortality rates in older patients with STEMI are higher than in younger patients $[9,10]$. Our analysis, nevertheless, showed that age-adjusted differences for STEMI mortality remained significantly higher in Oman and Yemen, suggesting that age differences alone could not explain the disparity in STEMI mortality.
The Gulf RACE was developed by the Gulf Heart Association to provide information about the process of care and outcomes of patients with ACS in this region of the Middle East. Because of the unique requirement of the registry protocol, mandating the coverage of at least $85 \%$ of each participating country, we have been able to study each country's STEMI mortality relating to the practice of ACS in a 'real world' setting. We found the unadjusted mortality in hospitalized STEMI patients in the Middle Eastern Gulf region to be 6.3\%. This is similar to the mortality rates reported by the Global RACE study (4-7\%), which evaluated about 11,543 patients from 94 hospitals in 14 countries [11-13]. However, a slightly lower crude inhospital mortality rate than ours was reported by a recent Australian audit [14]. Since our patients were almost 10 years younger than those in the Global RACE and the Australian audit, there is a potential for further reduction in our mortality rates. On the other hand, a recent Indian registry (CREATE) that studied over 20,000 ACS patients at similar ages to those of our patient population reported higher mortality rates of $5.5-8.2 \%$ [15]. 
When factors related to patient care and presentation were evaluated as factors that may explain the excess morality in Yemen and Oman, we noted several significant relationships. There was a delay in presentation to hospitals in Yemen and Oman, and consequently many patients missed the opportunity for reperfusion therapy. Furthermore, Oman and Yemen had the lowest rates of early thrombolysis and primary PCI in the region with higher rates of reperfusion shortfall. Yemen and Oman are geographically much larger than the rest of the countries in the registry, and hospital coverage for the population is much more restricted than in other Gulf countries. This might have been the reason behind the delayed hospital presentation and lower reperfusion rate. Previous studies suggest that when regional differences are detected they can be linked to higher revascularization rates and not to the baseline patient characteristics [16, 17]. Reductions in barriers to timely administration of thrombolytic therapy were previously shown to result in improved survival [18]. This is an area where appropriate health service interventions may lead to reduction in mortality [19-21].

In addition to differences in reperfusion therapy, the difference in use of evidence-based medications, particularly angiotensin-converting enzyme inhibitor/angiotensin receptor blocker and statin, may explain some of the significant excess mortality. This is important because an increased use of thrombolysis and a moderate increase in use of angiotensin-converting enzyme inhibitor has been shown to be associated with parallel reduction in ageadjusted mortality [22]. It should also be noted that the risk factor profiles as well as the clinical features at admission also differed between countries. There were more females in Yemen and Oman. Gender-related differences in early outcomes have been observed to be worse in women following acute myocardial infarction [23]. Researchers have suggested that women present late after first symptoms of myocardial infarction, which is more often unrecognized.

Several limitations of our study should be noted. The main limitation of this registry is the absence of longterm follow up. Another limitation is the lack of detailed data with respect to contraindications to medications needed to properly assess the use of medications in eligible patients. However, given that this study analyzed data from the first and possibly the largest multicountry, multicenter registry of ACS in the Middle East and captured a good proportion of consecutive patients gives utility to our data.

\section{Conclusion}

We found significant disparity in STEMI mortality in the Middle East. We also identified variability in a number of practice pattern factors such as reperfusion therapy, timely presentation and use of evidence-based medications. These findings are a cause for concern to local physicians and health care providers. These groups need to work together to establish policies that diminish ACS mortality in general and abolish the mortality disparity in these geographically and socially related countries.

\section{Appendix}

Gulf RACE National Coordinators and Investigators: Bahrain: Haitham Amin (National Coordinator), Husam Noor, Rashid Albannai. Kuwait: Bassam Bulbanat (National Coordinator), Shahid Zubair, Mustafa M. Ridha, Marwan Abu Rezq, Hesham Saad, Mousa Akbar, Rashed Al-Hamdan, Fahad Al-Enizi. Oman: Jawad Al-Lawati (National Coordinator), Kadhim Sulaiman (National Coordinator), B. Kamath, P.P. Singh, Marei Aysha, Ali Yousif, Faisal Tamimi, Kurain Mathew, Ahmed Mosad, A. Narayan, Adel Badr Eldin, Qassim Shimal, S.K. Samantray, Kamiran Dabagh, Zakaria Boghdady, K.J. Sulaiman, Sulieman Al-Sheraiqi. Qatar: Nidal A. Asaad (National Coordinator), Amar Mohammad Salam. United Arab Emirates: Nazar Albustani (National Coordinator), Srinath Kidambi, Vipin Thomas, Afzal Y. Ali, Nayan Rao, V.J. Sebastian, Wael El-Abbassi, Mohamed Ibrahim, M. Taiseer El-Massri, Adel A.S. Wassef, Amrish Agrawal, Joseph Kurein, Anthony Thomas, Ismail Jalian. Yemen: Ahmed Al-Motarreb (National Coordinator), Nora Al-Sagheer, Abdu Hamood, Mohammed Abu Ghanem, Abd Al-Jalil Al Wazeer, Abdullah AlShameeri, Majed Al-Showbaki, Elham Al-Qudari, Araf Ahamed Saleh, Hanan Mojamal, Abd Al-Raheem ba Khashwen, Faiz Khoba, Abd Al-Hakim Al-Hammadi, Munir Al-Absi, Mohammad Tantawi, Khalad Al-Zanan, Ahmed Al-Rubaidi, Faud Ali, Abd ARakeeb Al-GHobari, Madian Shehab, Motee Al-Awlagi.

\section{Acknowledgments}

Gulf RACE is a Gulf Heart Association project and was financially supported by Sanofi Aventis and Qatar Telecommunications Company. The sponsors had no role in study design, data collection or data analysis. The sponsors had no role in the writing of the report and submission of the manuscript. The study obtained ethical approval prior to the study. Special thanks to the physicians who participated in this registry, whose names are listed in the Appendix. We thank Dr. Hajar Albinali, President of the Gulf Heart Association, for his leadership and tremendous support for conducting this study. Special thanks to Dr. Hisham Mahmoud (Medical Director, Sanofi Aventis, Gulf) for his support during the course of the study, and to Miss Rihab Moneer, MSc, for her technical assistance in preparing the manuscript. 


\section{References}

1 Moise P, Jacobzone S, ARD-IHD Experts Group: Outcomes of interventions for IHD; in Moise P, Jacobzone S, ARD-IHD Experts Group: OECD Study of Cross-National Differences in the Treatment, Costs and Outcomes of Ischaemic Heart Disease. Paris, OECD, 2003, chapt 5, pp 70-79.

$\checkmark 2$ Chang WC, Midodzi WK, Westerhout CM, Boersma E, Cooper J, Barnathan ES, Simoons ML, Wallentin L, Ohman EM, Armstrong PW: Are international differences in the outcomes of acute coronary syndromes apparent or real? A multilevel analysis. J Epidemiol Community Health 2005;59:427-433.

- 3 O'Connor GT, Quinton HB, Traven ND, Ramunno LD, Dodds TA, Marciniak TA, Wennberg JE: Geographic variation in the treatment of acute myocardial infarction: the Cooperative Cardiovascular Project. JAMA 1999;281:627-633.

-4 Lopez AD, Mathers CD, Ezzati M, Jamison DT, Murray CJ: Global and regional burden of disease and risk factors, 2001: systematic analysis of population health data. Lancet 2006;367:1747-1757.

5 Menon V, Rumsfeld JS, Roe MT, Cohen MG, Peterson ED, Brindis RG, Chen AY, Pollack CV Jr, Smith SC Jr, Gibler WB, Ohman EM: Regional outcomes after admission for highrisk non-ST-segment elevation acute coronary syndromes. Am J Med 2006;119:584590.

6 Yusuf S, Reddy S, Ounpuu S, Anand S: Global burden of cardiovascular diseases. Part 2. Variations in cardiovascular disease by specific ethnic groups and geographic regions and prevention strategies. Circulation 2001; 104:2855-2864.

7 Zubaid M, Rashed WA, Al-Khaja N, Almahmeed W, Al-Lawati J, Sulaiman K, Al-Motarreb A, Amin H, Al-Suwaidi J, Al-Habib K: Clinical presentation and outcomes of acute coronary syndromes in the Gulf Registry of Acute Coronary Events (Gulf RACE). Saudi Med J 2008;29:251-255.

$\checkmark 8$ Cannon CP, Battler A, Brindis RG, Cox JL, Ellis SG, Every NR, Flaherty JT, Harrington RA, Krumholz HM, Simoons ML, van de Werf FJ, Weintraub WS, Mitchell KR, Morrisson SL, Brindis RG, Anderson HV, Cannom DS, Chitwood WR, Cigarroa JE, Collins-Nakai RL, Ellis SG, Gibbons RJ, Grover FL, Heidenreich PA, Khandheria BK, Knoebel SB, Krumholz HL, Malenka DJ, Mark DB, Mckay CR, Passamani ER, Radford MJ, Riner RN, Schwartz JB, Shaw RE, Shemin RJ, van Fossen DB, Verrier ED, Watkins MW, Phoubandith DR, Furnelli T: American College of Cardiology key data elements and definitions for measuring the clinical management and outcomes of patients with acute coronary syndromes: a report of the American College of Cardiology Task Force on Clinical Data Standards (Acute Coronary Syndromes Writing Committee). J Am Coll Cardiol 2001;38:2114-2130.

$\checkmark 9$ de Labriolle A, Giraudeau B, Pacouret G, Desveaux B, Quilliet L, Charbonnier B, Fauchier L: Revascularization algorithm in acute STEMI should take into account age. Cardiovasc Revasc Med 2007;8:90-93.

10 Gregoratos G: Clinical manifestations of acute myocardial infarction in older patients. Am J Geriatr Cardiol 2001;10:345347.

11 Granger CB, Steg PG, Peterson E, LópezSendón J, van de Werf F, Kline-Rogers E, Allegrone J, Dabbous OH, Klein W, Fox KA, Eagle KA, GRACE Investigators: Medication performance measures and mortality following acute coronary syndromes. Am J Med 2005;118:858-865.

12 Steg PG, Goldberg RJ, Gore JM, Fox KA, Eagle KA, Flather MD, Sadiq I, Kasper R, Rushton-Mellor SK, Anderson FA, GRACE Investigators: Baseline characteristics, management practices, and in-hospital outcomes of patients hospitalized with acute coronary syndromes in the Global Registry of Acute Coronary Events (GRACE). Am J Cardiol 2002;90:358-363.

13 Budaj A, Brieger D, Steg PG, Budaj A, Brieger D, Steg PG, Goodman SG, Dabbous OH, Fox KA, Avezum A, Cannon CP, Mazurek T, Flather MD, van de Werf F: Global patterns of use of antithrombotic and antiplatelet therapies in patients with acute coronary syndromes: insights from the Global Registry of Acute Coronary Events (GRACE). Am Heart J 2003;146:999-1006.

14 Chew DP, Amerena J, Coverdale S, Rankin J, Astley C, Brieger D: Current management of acute coronary syndromes in Australia: observations from the acute coronary syndromes prospective audit. Intern Med J 2007; 37:741-748.

15 Xavier D, Pais P, Devereaux PJ, Xie C, Prabhakaran D, Reddy KS, Gupta R, Joshi P, Kerkar P, Thanikachalam S, Haridas KK, Jaison TM, Naik S, Maity AK, Yusuf S: Treatment and outcomes of acute coronary syndromes in India (CREATE): a prospective analysis of registry data. Lancet 2008;371: 1435-1442.

16 Gupta M, Chang WC, van de Werf F, Granger CB, Midodzi W, Barbash G, Pehrson K, Oto A, Toutouzas P, Jansky P, Armstrong PW: International differences in hospital revascularization and outcomes following acute myocardial infarction: a multilevel analysis of patients in ASSENT-2. Eur Heart J 2003;24:1640-1650.
17 Giugliano RP, Llevadot J, Wilcox RG, Gurfinkel EP, McCabe $\mathrm{CH}$, Charlesworth A, Thompson SL, Antman EM, Braunwald E: Geographic variation in patient and hospital characteristics, management and clinical outcomes in ST-elevation myocardial infarction treated with fibrinolysis: results from InTIME-II. Eur Heart J 2001;22:17021715.

18 Fox KA, Goodman SG, Klein W, Brieger D, Steg PG, Dabbous O, Avezum A: Management of acute coronary syndromes: variations in practice and outcome - findings from the Global Registry of Acute Coronary Events (GRACE). Eur Heart J 2002;23:11771189.

19 Yusuf S, Flather M, Pogue J, Hunt D, Varigos J, Piegas L, Avezum A, Anderson J, Keltai M, Budaj A, Fox K, Ceremuzynski L: Variations between countries in invasive cardiac procedures and outcomes in patients with suspected unstable angina or myocardial infarction without initial ST elevation. OASIS (Organization to Assess Strategies for Ischemic Syndromes) Registry Investigators. Lancet 1998; 352:507-514.

20 Hasdai D, Behar S, Wallentin L, Danchin N, Gitt AK, Boersma E, Fioretti PM, Simoons ML, Battler A: A prospective survey of the characteristics, treatments and outcomes of patients with acute coronary syndromes in Europe and the Mediterranean basin: the Euro Heart Survey of Acute Coronary Syndromes (Euro Heart Survey ACS). Eur Heart J 2002;23:1190-1201.

21 Mandelzweig L, Battler A, Boyko V, Bueno H, Danchin N, Filippatos G, Gitt A, Hasdai D, Hasin Y, Marrugat J, van de Werf F, Wallentin L, Behar S: The second Euro Heart Survey on acute coronary syndromes: characteristics, treatment, and outcome of patients with ACS in Europe and the Mediterranean Basin in 2004. Eur Heart J 2006;27: 2285-2293.

22 Herlitz J, Dellborg M, Karlson BW, Herlitz J, Dellborg M, Karlson BW, Lindqvist J, Karlsson T, Sandén W, Sjölin M, Wedel H: Changes in the use of medications after acute myocardial infarction: possible impact on mortality after myocardial infarction and long-term outcome. Coron Artery Dis 2001; 12:61-67.

23 Dilmanian H, Aronow WS, Das M, Pucillo AL, Weiss MB, Kalapatapu K, Monsen CE: In-hospital mortality and time from onset of symptoms of acute myocardial infarction in 540 patients undergoing primary coronary angioplasty: comparison between blacks, whites and patients of other races, and between men and women. Cardiology 2007; 107:107-110. 